УДК 378.091.3:004.9

UDC 378.091.3:004.9

DOI: $10.31475 /$ ped.dys.2021.30.03

OLEKSANDR STEPANOV,

Candidate of Veterinary Sciences, Associate Professor (Ukraine, Kamianets-Podilskyi, State Agrarian and Engeneering University of Podillia, Shevchenco St., 13)

ОЛЕКСАНДР СТЕПАНОВ, кандидат ветеринарних наук, доцент (Украӥна, Кам’янеиь-Подільський, Подільський державний аграрно-технічний університет, вул. Шевченка, 13)

ORCID: $\underline{0000-0003-2432-0490}$

\title{
Usage of the Educational Video by Students-Veterinarians Who are Studying Operative Surgery
}

\section{Використання навчального відео студентами-ветеринарами, що вивчають оперативну хірургію}

Підготовка ветеринарних хірургів в уловах, які не дозволяють проводити оперативні втручання, вилагае використання сучасних інтерактивних засобів навчання. До таких належить навчальне хірургічне відео. Забезпечуючи слухове і зорове сприйняття інборлації воно володіє високою інфорлативністю.

Хірургічне відео дає можливість донести до кожного студента всі тонкощі тієї чи іншої операцї, не вилагаючи його присутності на ній, дозволяє делонструвати всі стадї процесу, перебуваючи в найбільш колфортній для сприйняття точиі. Перегляд якісного відео, шјо відтворює небезпечну роботу хірурга, без ризику повною мірою сприяє засвоєнню необхідного матеріалу. Іще однією важливою перевагою навчального відео $\epsilon$ те, що студент його ложе переглядати салостійно, з метою ознайоллення або повторення матеріалу, а також зберігати на дискових носіях.

У проиесі досліджень був проведений аналіз наукових джерел про застосування навчального відео у вищій школі. 3 метою отрилання даних стосовно використання хірургічного відео студентали, шо вивчають оперативну хірургію, застосовувалися такі соціологічні методи, як опитування, спостереження, анкетування.

Згідно отриланих даних при вивченні оперативної хірургї всі студенти використовують конспект аудиторних занять та хірургічне відео, 75\% з них користується підручником $i$ 25\% хірургічнили сайтали.

Разол з тил, з числа тих, хто бере інборлацію на хірургічних сайтах, 70\% шукають текстові матеріали і 30\% переглядають фото та рисунки.

При підготовиі до реальної операцї̈ всі студенти віддають перевагу відео, на яколу показана вся операція від початку до кіния. 3 навчальною метою такий ббільл хотіли б переглянути з/4 опитаних студентів, а для інших вистачає короткої версї.

50\% студентів після першого перегляду навчального відео з тели в лекційній аудиторї вдола шукають подібні латеріали $і$ знову переглядають їх а також скачують на свої носї інборлаиї.

Проведена робота відкриває перспективу подальших досліджень застосування хірургічного відео при підготовиі ветеринарних хірургів.

Ключові слова: ветеринарна хірургія, оперативна хірургія, навчальне відео, хірургічне відео, навчальний матеріал, конспект, підручник.

The training of veterinary surgeons, in conditions that do not allow for surgical intervention, requires the use of modern interactive teaching aids. These include educational surgical video. Providing auditory and visual perception of information, it has high informative character.

Surgical video gives the opportunity to communicate to each student all the intricacies of the operation, without requiring its presence on it, allows you to demonstrate all stages of the process, being in the most comfortable point of perception. Watching a high-quality video that reproduces the dangerous work of a surgeon without risk completely helps to master the necessary material. Another important advantage of the educational video is that the student can view it on his own, in order to acquaint or repeat the material, as well as to store it on disk media.

In the course of research, an analysis of scientific sources on the use of educational videos in higher education was conducted. In order to obtain data on the use of surgical video, by the students studying 
operative surgery, were used such sociological methods as surveys, observations, questionnaires.

According to the data obtained in the study of operative surgery, all students use the abstract of classroom lessons and surgical video. $75 \%$ of them use the textbook and $25 \%$ of the surgical sites. However, among those who take information on surgical sites, $70 \%$ are looking for text materials and $30 \%$ are browsing photos and pictures. In preparation for a real operation, all students prefer a video showing the entire operation from beginning to end. With the educational purpose of such a movie would be to view $3 / 4$ of the students surveyed, and for others it is short enough. $50 \%$ of the students after the first review of the video tutorial on the topic in the lecture room at home look for similar materials and revisit them as well as download their media.

The work opens the prospect of further research on the use of surgical video in the preparation of veterinary surgeons.

Key words: veterinary surgery, operational surgery, educational video, surgical video, educational material, conspectus, schoolbook.

Introduction / Вступ. An important stage in the training of veterinarians is the students' mastery of the course of operative surgery. It consists of classroom and individual lessons as well as independent work. The specifics of operative surgery, as a practical discipline, require the teacher to fill these classes as much as possible with a demonstration of special techniques and surgical interventions related to a particular topic.

Research shows that accompanying a story with an illustration of what is being studied significantly increases the level of mastery. Thus, the efficiency of auditory perception of information is $15 \%$, visual $-25 \%$, and their simultaneous inclusion in the learning process increases the efficiency of perception to $65 \%$ (Slastenin V., Isaev I. \& Shiyanov E., 2014).

In other words, for better mastering of surgery, the student should see the process of surgery. Moreover, it is better when it happens «live». It is not possible to perform operations on animals at every lecture. To ensure this, it would be necessary to increase the number of teaching hours several times. However, due to the development of information technology, teachers get a unique opportunity to accompany their lecture material with audio and video presentations.

Modern computer technologies make it possible to qualitatively convey to each student the educational information he/she needs (Stepanov O., 2017).

Not so long ago, to see the operation, a student had to be present at it. Given that there is not much place for an outside observer at the operating table, the vast majority of students had to observe the surgeon's work from behind the backs of their peers. Such a position may not always provide sufficient visual access to the operated area, which reduces the learning effectiveness of the demonstration of the course of surgery. With the advent of educational films on operative surgery, it became possible to convey to each student all the intricacies of a particular operation, without requiring his/her presence on it.

During the Soviet period, there were production plants that produced educational films. Today, they are outdated and require equipment that is usually gone. However, modern multimedia technologies using the Internet allow the teacher to get, in fact, any educational video he/she needs, and show students in class.

YouTube video hosting is popular among veterinary students. It contains a huge number of educational videos of surgical interventions and surgical care (Stepanov O., 2020).

At the same time, it is optimal to show a video on which the teacher's work is reproduced. This personalizes the presented material, which is very important for students' perception of such a discipline as operative surgery.

The training video allows you to demonstrate all stages of the process, being in the most comfortable viewing point. In this case, it is usually accompanied by an audio commentary. Optimal for perception is the original sound recording, which contains all the surgeon's commands as well as the voice sounds of the animal. This provides the effect of presence on the operation. In the absence of a recorded comment, it should be provided by the teacher, explaining all the operational techniques.

If the work is performed in a body cavity or in a tissue to which access is limited, a conventional video camera cannot record the actions performed, however, modern animation tools allow you to visualize the whole process.

By showing the educational film, the teacher can not only accompany it with his/her explanations but also directly control the viewing, stopping, or slowing down the video. This makes it possible to emphasize individual details by explaining them. Also, if necessary, he/she can scroll the video back and play the desired fragment again.

Performing certain surgeries with animals can be dangerous for the surgeon and his/her assistants. At the same time, students can observe their actions only at a sufficient distance, in a safe place. 
However, watching a high-quality video that reproduces the dangerous work of the surgeon, fully contributes to the assimilation of the necessary material.

Another important advantage of educational video is that the student can watch it on their own, to get acquainted or repeat the material.

As one of the products of new information technologies, educational video can be easily distributed among Internet users as well as on disk media.

Aim and Tasks / Мета та завдання. The purpose of the research was to determine which textbooks students who study operative surgery prefer, as well as their use of educational videos to study this discipline and improve their professional training. Objectives: To determine which sources of educational information students use in preparation for classes in operative surgery; to investigate the nature of educational materials used by students; establish students' attitudes to watching surgical videos for training and to enhance surgical competence.

Methods / Методи. The research work was carried out on a group of third-year students of the Faculty of Veterinary Medicine and Technology in Animal Husbandry of Podilskiy State Agrarian Technical University in the amount of 40 people. In the course of research, the sources of information on the use of educational videos in higher education were analysed. To obtain data on the use of educational videos, students studying operative surgery used such methods as surveys, observations, questionnaires.

Results / Результати. According to the research (Fig. 1), all surveyed students studying operative surgery use lecture notes and notebooks for laboratory classes in the discipline, $75 \%$ of students use textbooks and $25 \%$ seek additional information on surgical sites.

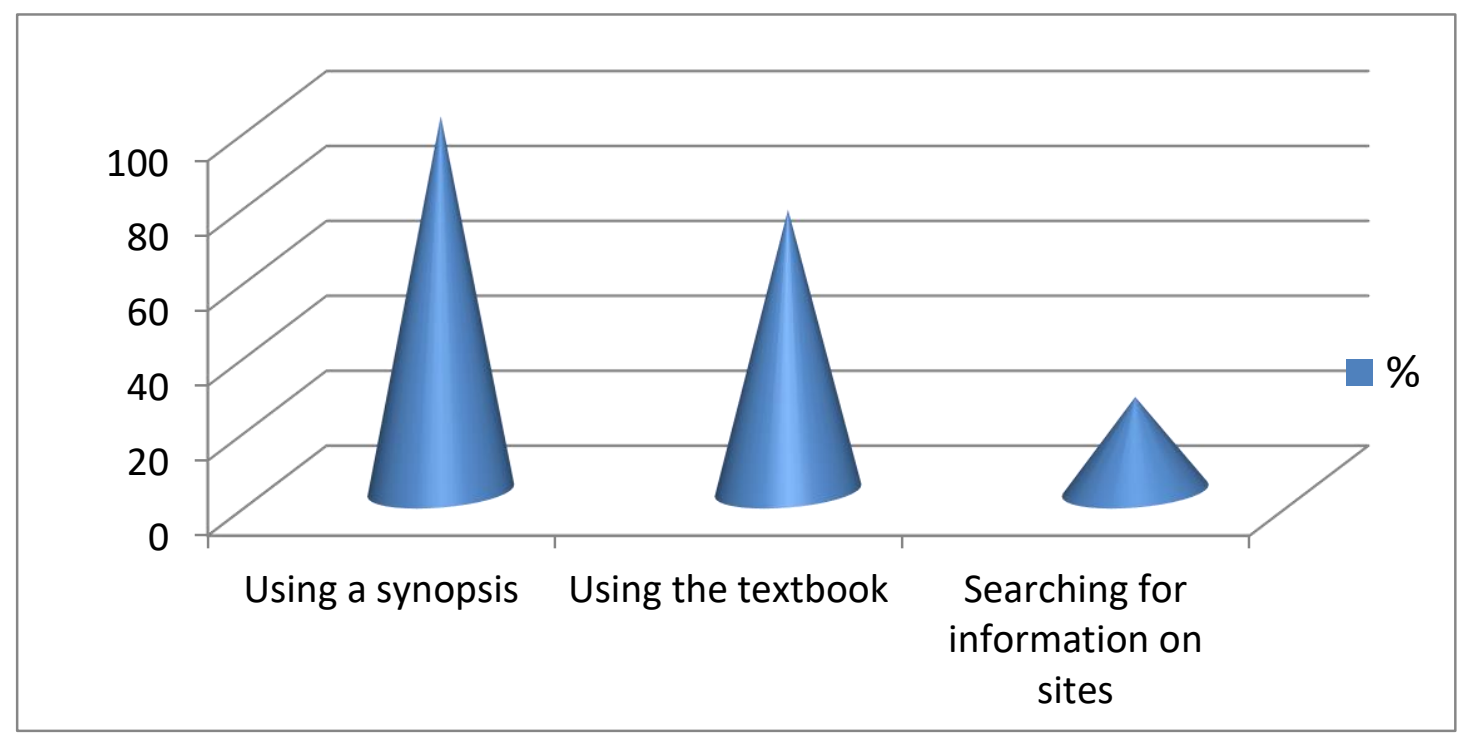

Fig. 1 Students' use of information sources

According to our data, in preparation for classes, all students, without exception, watch surgical videos, and among those students who use specialized sites, $70 \%$ read text materials from the Internet, and $30 \%$ view photos and pictures (Fig. 2). 


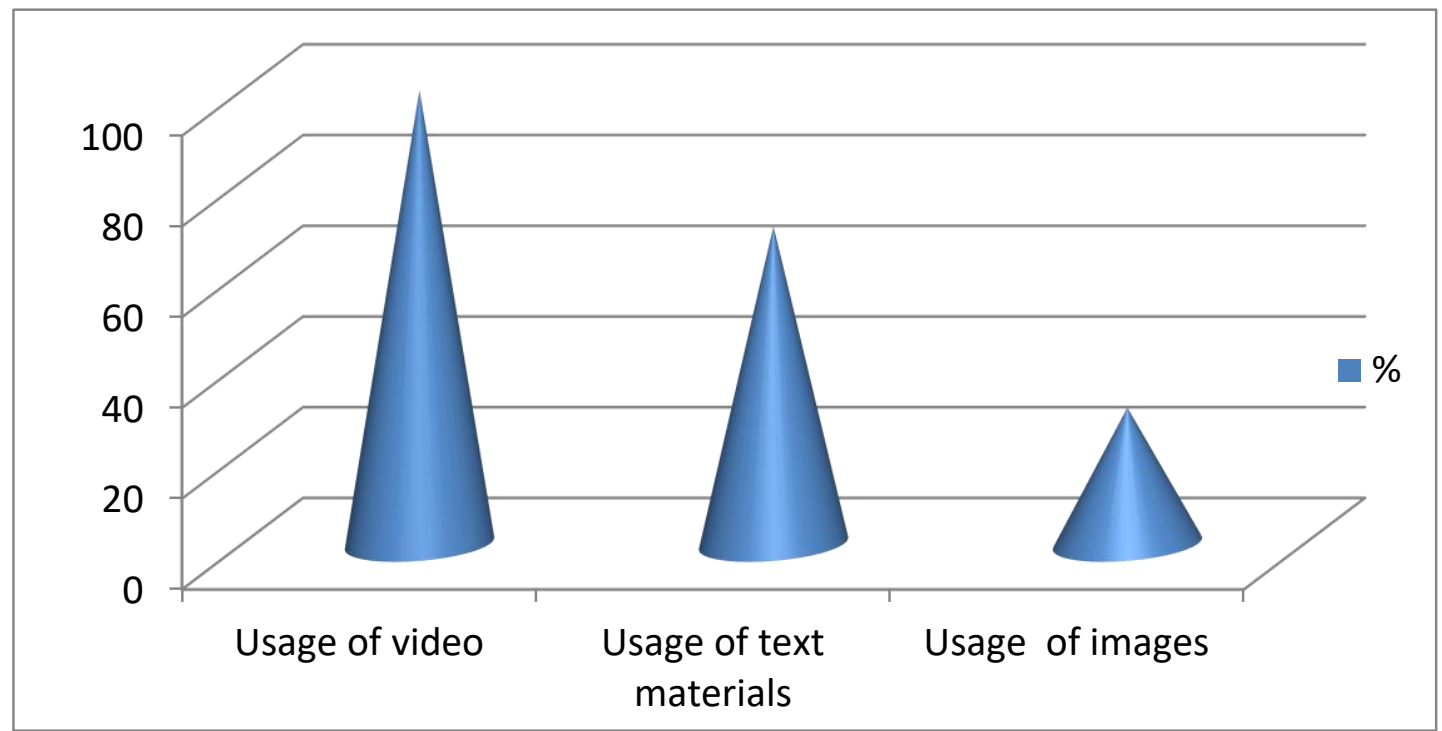

Fig. 2 Use of training materials and surgical video

However, it is noted that students have different attitudes to the surgical video depending on the purpose of viewing.

As shown in Figure 3, in preparation for the operation in which students will participate, or for practical purposes, they prefer a complete, realistic video showing the entire operation. For theoretical purposes, for acquaintance, the full video is chosen by $75 \%$ of students, the other quarter is satisfied with the short version.

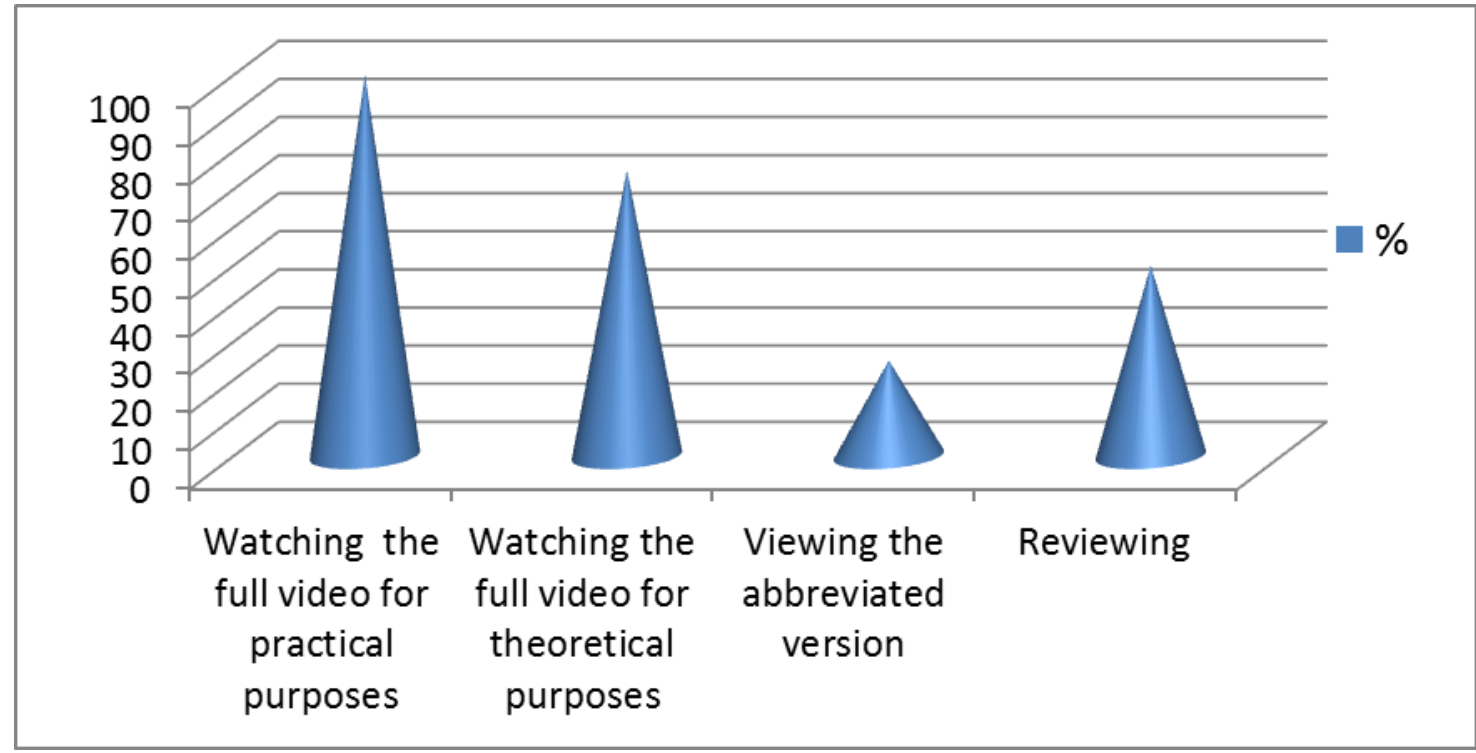

Fig. 3 Surgical video viewing

The results of the research showed that $50 \%$ of students after the first viewing of the educational video on the topic in the lecture hall, look for similar materials and review them again and also download them to their media at home.

Discussion / Обговорення. According to C. Brame (2015), video has become part of higher education. It is integrated into traditional courses, is the cornerstone of many blended courses, and is often the main mean of conveying information in online courses.

I. Basev (2015) concluded that video lessons give students additional advantages over classroom classes: there is no need to take notes, there is a possibility of revision, the material can be studied anywhere, not just in college.

O. Terpugova (2015) shows that video is a good basis for discussions, which helps to demonstrate the theory, and shows experiments that can not be performed in the classroom, as well as qualitatively improves the educational material.

According to S. June, A. Yaacob, \& Y. Kheng (2014), YouTube video has a positive effect on learning from a variety of disciplines. 
According to A. Thomsen, R. Bridgstock, \& C. Willems (2014), the use of video has increased student attendance and interest. Similar data were also obtained by R. Schmid, R. Bernard, \& E. Borokhovski (2014).

According to research by B. Stockwell, M. Stockwell, \& M. Cennamo (2015), video is of particular importance for preparing students for classes, including through the recognition of it as a more attractive means of learning. And according to S. Dash, U. Kamath, \& G. Rao (2016) due to the fact that it allows you to visualize difficult-to-understand and abstract phenomena.

J. Stigler, E. Geller, \& K. Givvin (2015) concluded that video will play a major role in learning in the future.

There is information about using YouTube videos for teaching medical disciplines. In an anatomy course that included YouTube, $98 \%$ of students watched assigned videos, and $92 \%$ said they were useful in studying anatomical areas of the body (Jaffar A., 2012).

The importance of YouTube in dentistry and dental education was also assessed. Dental videos classified as «educational» were rated as having great educational value (Knösel M., Jung K. \& Bleckmann A., 2011).

The University of Veterinary Medicine in Hanover has created its own YouTube channel «TiHoVideos», which aims to provide public access to educational videos for better mastery of clinical skills by students. The results show that the best learning performance was achieved by students who prepared for classes by watching TiHoVideos at home on tablets or laptops, and then practiced in classrooms (Müller L., Tipold A., Ehlers J. \& Schaper E., 2019).

According to Dilly M., Tipold A., Schaper E. \& Ehlers J. (2014), video is useful not only for teaching and preparing for a session but also for testing or improving certain skills.

Helen F., Oprescu F., Downer T., \& Phillips N., (2016) also agree with this statement, who view video as a learning strategy that can improve students' acquisition of clinical skills.

E. Coyne, H. Rands, V. Frommolt \& V. Kain (2018) report that a blended learning model that includes online video resources can be a useful tool for acquiring clinical skills for students. Blended learning not only improves their knowledge and skills, but it is often chosen by students because of its informativeness.

The use of simulation videos on a blended learning platform allows students to review best practices and provides appropriate links between theory and practice (Coyne E., Frommolt V., Rands H., \& Kain V., 2018).

At the same time, for the acquisition of clinical skills for future physicians, video cannot replace practical work in classrooms. Students value full-time tutoring, and video can be used as a learning supplement to improve knowledge (Stone R., Cooke M., \& Mitchell M., 2020).

Thus, teaching methods using video technologies and traditional teaching methods used together create the most positive learning environment (Stone R., Cooke M., \& Mitchell M., 2020).

The analysis of scientific publications gives grounds to claim that the problem of using educational video in training is relevant.

As our research has shown, all surveyed students use lecture notes. This is obviously because students trust the teacher to give only the necessary information. Whereas textbooks quickly lose relevance. As a result, only $75 \%$ of respondents use textbooks.

However, some students (25\%) are not limited to the syllabus and textbook but look for the necessary information on surgical sites. As a rule, they find there mostly texts from textbooks of different years or, at best, scientific articles.

All students watch the surgical video in preparation for classes. Such interest of students is connected with its highly informative.

The information that the student receives during the review is better absorbed, in addition, he/she has a clear idea of the features of the intervention, which does not happen in the case of viewing tables, slides, or perception of textual material.

In each case, when the video is not used, the student at the illusory level is forced to create "moving pictures" of certain operational techniques, the combination of which provides his/her vision of the educational material and the degree of mastery of it.

Errors are possible. They further weaken the imagination of the student, who cannot fill the information gaps during learning new material by simply listening to a lecture or seeing individual thematic images.

This is due to the errors in the answers of conscientious students who, in their opinion, have studied a certain surgical intervention.

These learning deficits depend not so much on the intellectual ability of the student, but, to a much greater extent, on the experience of such practical work or, again, on the viewing of such a video.

The informativeness of the video itself is important. If a student sees only a few clips of sliced, 
though the main moments of a major operation, there's a lot that's out of his sight. A complete view can only be provided by as realistic a video as possible, which creates a presence effect on the operation.

Students who like surgery and who try to understand the intricacies of an operation prefer realistic video. However, some students review abbreviated versions of surgical interventions or excerpts from them. They explain this by trying to reduce the time required to master the material, as well as the lack of personal interest in deep acquaintance due to the reluctance to perform similar work in the future.

Those students who, after watching the video in the classroom, download it to their media, aim to consolidate the mastered material, and if necessary, quickly repeat.

Conclusions / Висновки. Thus, summarizing the above, it can be argued that all students studying operative surgery use the syllabus and surgical video, $75 \%$ of them use the textbook, and $25 \%$ of surgical sites.

At the same time, $70 \%$ of students who take information on surgical sites, look for text materials, and $30 \%$ view photos and pictures.

In preparation for the actual operation, all students prefer the video, which shows the entire operation from start to finish. For educational purposes, such a film would like to watch $3 / 4$ interviewed students and for others, a short version is enough.

Half of the students after the first viewing of the educational video on the topic in the lecture hall look for similar materials and review them again and download them to their media at home.

This work opens the prospect of further research into the use of surgical video in the training of veterinary surgeons.

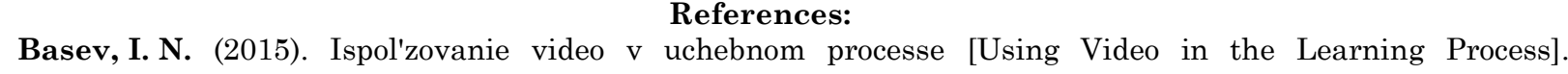
Perspektivy razvitiya informacionnyh tekhnologij - Prospects for the Development of Information Technology, 24, 130-133. Retrieved from https://cyberleninka.ru/article/n/ispolzovanie-video-v-uchebnom-protsesse [in Russian].

Slastenin, V. A., Isaev, I. F., \& Shiyanov, E. N. (2014). Pedagogika [Pedagogy]. Moscow: Akademiya. Retrieved from https://nashol.me/2016010887887/pedagogika-slastenin-v-a-isaev-i-f-shiyanov-e-n-2014.html [in Russian].

Stepanov, O. D. (2017). Vykorystannia internet-tekhnolohii i sotsialnykh merezh studentamy mahistratury, shcho vyvchaiut khirurhichni khvoroby tvaryn [Use of Internet Technologies and Social Networks by Master's Students Studying Surgical Diseases of Animals]. Profesiino-prykladni dydaktyky - Professional and Applied Didactics, 3, 239-247 [in Ukrainian].

Stepanov, O. D. (2020). Vykorystannia sotsialnykh merezh studentamy-veterynaramy, shcho vyvchaiut veterynarnu hirurhiiu [Use of Social Networks by Students-Veterinarians Studying Veterinary Surgery]. Pedahohichnyi dyskurs - Pedagogical Discourse, 28, 32-38. Retrieved from https://doi.org/10.31475/ped.dys.2020.28.04 [in Ukrainian].

Terpugova, O. A. (2015). Video na uchebny'x zanyatiyax [Video in Training Sessions]. Problemy'i perspektivy' fiziko-matematicheskogo i texnicheskogo obrazovaniya - Problems and Prospects of Physical-Mathematical and Technical Education: proceeding's of the conference (p. 191-195) Ishim. Retrieved from https://www.elibrary.ru/download/elibrary 25633003 94994027.pdf [in Russian].

Brame, C. J. (2015). Effective educational videos: Principles and guidelines for maximizing student learning from video content. Cell Biology Education - Life Sciences Education, 15, 4, 1-6. Retrieved from http://www.lifescied.org/content/15/4/es6.full.pdf+html [in English].

Coyne, E., Frommolt, V., Rands, H., \& Kain, V. (2018). Simulation videos presented in a blended learning platform to improve Australian nursing students' knowledge of family assessment. Nurse Educ Today, 66, 96-102. Retrieved from https://doi.org/doi:10.1016/j.nedt.2018.04.012 [in English].

Dash, S., Kamath, U., \& Rao, G. (2016). Audio-visual aid in teaching «fatty liver». Biochem Mol Biol Educ., 44, 241-245. Retrieved from https://doi.org/10.1002/bmb.20935 [in English].

Dilly, M., Tipold, A., Schaper, E., \& Ehlers, J. (2014). Etablierung eines Skills Labs in der Tiermedizin in Deutschland. GMS Z Med Ausbild., 31 (2), 20. Retrieved from https://doi.org/10.3205/zma000912 [in English].

Elisabeth, C., Rands, H., Frommolt, V., \& Kain, V. (2018). Investigation of blended learning video resources to teach health students clinical skills: An integrative review. Nurse Educ Today, 63, 101-107. Retrieved from https://doi.org/doi:10.1016/j.nedt.2018.01.021 [in English].

Forbes, H., Oprescu, F. I, Downer, T., \& Phillips, N. M. (2016). Use of videos to support teaching and learning of clinical skills in nursing education: A review. Nurse Educ Today, 42, 53-56. Retrieved from https://doi.org/10.1016/j.nedt.2016.04.010 [in English].

Jaffar, Akram Abood (2012). "YouTube: An emerging tool in anatomy education». Anatomical Sciences Education, 5 (3), 158-164. Retrieved from https://doi.org/10.1002/bmb.20935 [in English].

June, S., Yaacob, A., \& Kheng, Y. K. (2014). Assessing the Use of YouTube Videos and Interactive Activities as a Critical Thinking Stimulator for Tertiary Students: An Action Research. International Education Studies. 7, 8, 56-67. Retrieved from https://doi.org/10.5539/ies.v7n8p56 [in English].

Knösel, M., Jung, K., \& Bleckmann, A. (2011). «YouTube, Dentistry, and Dental Education». Journal of Dental Education, 75 (12), 1558-1568. Retrieved from https://pubmed.ncbi.nlm.nih.gov/22184594/ [in English].

Müller, L. R., Tipold, A., Ehlers, J. P., \& Schaper, E. (2019). TiHoVideos: veterinary students' utilization 
of instructional videos on clinical skills. BMC Vet Res., 11, 15(1), 326. Retrieved from https://doi.org/10.1186/s12917-019-2079-2 [in English].

Schmid, R. F., Bernard, R. M., \& Borokhovski, E. (2014). The effects of technology use in postsecondary education: A meta-analysis of classroom applications. Computers \& Education, 72, 271-291. Retrieved from https://doi.org/10.1016/j.compedu.2013.11.002 [in English].

Stockwell, B. R., Stockwell, M. S., \& Cennamo, M. (2015). Blended learning improves science education. Jiang. Cell., 162, 933-936. Retrieved from https://doi.org/10.1016/j.cell.2015.08.009 [in English].

Stone, R., Cooke, M., \& Mitchell, M. (2020). Exploring the meaning of undergraduate nursing students' experiences and confidence in clinical skills using video. Nurse Educ Today, 86, 104322. Retrieved from https://doi.org/10.1016/j.nedt.2019.104322 [in English].

Stone, R., Cooke, M., \& Mitchell, M. (2020). Undergraduate nursing students' use of video technology in developing confidence in clinical skills for practice: A systematic integrative literature review. Nurse Educ Today, 84, 104230. Retrieved from https://doi.org/10.1016/j.nedt.2019.104230 [in English].

Thomsen, A., Bridgstock, R., \& Willems, C. (2014). Teachers flipping out beyond the online lecture: Maximising the educational potential of video. Journal of Learning Design, 7, 67-78. Retrieved from https://www.jld.edu.au/article/view/209.html [in English].

\section{Список використаних джерел і літератури:}

Басев, И. Н. (2015). Использование видео в учебном процессе. Перспективы развития инфборлационных технологий, 24, 130-133. Взято с https://cyberleninka.ru/article/n/ispolzovanie-video-v-uchebnom-protsesse [in Russian].

Сластенин, В. А., Исаев, И. Ф., \& Шиянов, Е. Н. (2014). Педагогика. Москва: Академия. Взято с https://nashol.me/2016010887887/pedagogika-slastenin-v-a-isaev-i-f-shiyanov-e-n-2014.html [in Russian].

Степанов, О. Д. (2017). Використання інтернет-технологій і соціальних мереж студентами магістратури, що вивчають хірургічні хвороби тварин. Профбесійно-прикладні дидактики, 3, 239-247 [in Ukrainian].

Степанов, О.Д. (2020). Використання соціальних мереж студентами-ветеринарами, що вивчають ветеринарну хірургію. Педагогічний дискурс, 28, 32-38. Взято з https://doi.org/10.31475/ped.dys.2020.28.04 [in Ukrainian].

Терпугова, О. А. (2015). Видео на учебных занятиях. Проблемы и перспективы фбизикоматематического и технического образования: сб. материалов всерос. науч.-практ. конф. (с. 191-195) Ишим: Изд-во ИПИ им. П.П. Ершова. Взято с https://www.elibrary.ru/download/elibrary_25633003_94994027.pdf [in Russian].

Brame, C. J. (2015). Effective educational videos: Principles and guidelines for maximizing student learning from video content. Cell Biology Education - Life Sciences Education, 15, 4, 1-6. Retrieved from http://www.lifescied.org/content/15/4/es6.full.pdf+html [in English].

Coyne, E., Frommolt, V., Rands, H., \& Kain, V. (2018). Simulation videos presented in a blended learning platform to improve Australian nursing students' knowledge of family assessment. Nurse Educ Today, 66, 96-102. Retrieved from https://doi.org/doi:10.1016/j.nedt.2018.04.012 [in English].

Dash, S., Kamath, U., \& Rao, G. (2016). Audio-visual aid in teaching «fatty liver». Biochem Mol Biol Educ., 44, 241-245. Retrieved from https://doi.org/10.1002/bmb.20935 [in English].

Dilly, M., Tipold, A., Schaper, E., \& Ehlers, J. (2014). Etablierung eines Skills Labs in der Tiermedizin in Deutschland. GMS Z Med Ausbild., 31 (2), 20. Retrieved from https://doi.org/10.3205/zma000912 [in English].

Elisabeth, C., Rands, H., Frommolt, V., \& Kain, V. (2018). Investigation of blended learning video resources to teach health students clinical skills: An integrative review. Nurse Educ Today, 63, 101-107. Retrieved from https://doi.org/doi:10.1016/j.nedt.2018.01.021 [in English].

Forbes, H., Oprescu, F. I, Downer, T., \& Phillips, N. M. (2016). Use of videos to support teaching and learning of clinical skills in nursing education: A review. Nurse Educ Today, 42, 53-56. Retrieved from https://doi.org/10.1016/j.nedt.2016.04.010 [in English].

Jaffar, Akram Abood (2012). "YouTube: An emerging tool in anatomy education». Anatomical Sciences Education, 5 (3), 158-164. Retrieved from https://doi.org/10.1002/bmb.20935 [in English].

June, S., Yaacob, A., \& Kheng, Y. K. (2014). Assessing the Use of YouTube Videos and Interactive Activities as a Critical Thinking Stimulator for Tertiary Students: An Action Research. International Education Studies. 7, 8, 56-67. Retrieved from https://doi.org/10.5539/ies.v7n8p56 [in English].

Knösel, M., Jung, K., \& Bleckmann, A. (2011). "YouTube, Dentistry, and Dental Education». Journal of Dental Education, 75 (12), 1558-1568. Retrieved from https://pubmed.ncbi.nlm.nih.gov/22184594/ [in English].

Müller, L. R., Tipold, A., Ehlers, J. P., \& Schaper, E. (2019). TiHoVideos: veterinary students' utilization of instructional videos on clinical skills. BMC Vet Res., 11, 15(1), 326. Retrieved from https://doi.org/10.1186/s12917-019-2079-2 [in English].

Schmid, R. F., Bernard, R. M., \& Borokhovski, E. (2014). The effects of technology use in postsecondary education: A meta-analysis of classroom applications. Computers \& Education, 72, 271-291. Retrieved from https://doi.org/10.1016/j.compedu.2013.11.002 [in English].

Stockwell, B. R., Stockwell, M. S., \& Cennamo, M. (2015). Blended learning improves science education. Jiang. Cell., 162, 933-936. Retrieved from https://doi.org/10.1016/j.cell.2015.08.009 [in English].

Stone, R., Cooke, M., \& Mitchell, M. (2020). Exploring the meaning of undergraduate nursing students' experiences and confidence in clinical skills using video. Nurse Educ Today, 86, 104322. Retrieved from https://doi.org/10.1016/j.nedt.2019.104322 [in English].

Stone, R., Cooke, M., \& Mitchell, M. (2020). Undergraduate nursing students' use of video technology in 
developing confidence in clinical skills for practice: A systematic integrative literature review. Nurse Educ Today, 84, 104230. Retrieved from https://doi.org/10.1016/j.nedt.2019.104230 [in English].

Thomsen, A., Bridgstock, R., \& Willems, C. (2014). Teachers flipping out beyond the online lecture: Maximising the educational potential of video. Journal of Learning Design, 7, 67-78. Retrieved from https://www.jld.edu.au/article/view/209.html [in English].

Дата надходження статті: «25» березня 2021 р.

Стаття прийнята до друку: «20» квітня 2021 р.

Степанов Олександр - доцент кафедри ветеринарного акушерства, внутрішньої патології та хірургії Подільського державного аграрно-технічного університету, кандидат ветеринарних наук, доцент

Stepanov Oleksandr - Assistant Professor of the Department of Veterinary Obstetrics, Internal Pathology and Surgery of State Agrarian and Engeneering University of Podilya, Candidate of Veterinary Sciences, Associate Professor

\section{Цитуйте иљю статтю як:}

Степанов, О. (2021). Використання навчального відео студентами-ветеринарами, що вивчають оперативну хірургію. Педагогічний дискурс, 30, 2431. doi: 10.31475/ped.dys.2021.30.03.

\section{Cite this article as:}

Stepanov, O. (2021). Usage of the Educational Video by Students-Veterinarians Who are Studying Operative Surgery. Pedagogical Discourse, 30, 24-31. doi: 10.31475/ped.dys.2021.30.03. 